\title{
The Promise of Democracy for the Americas: U.S. Diplomacy and the Meaning(s) of World War II in El Salvador, 1941-1945
}

\author{
Jorrit van den Berk*
}

Warning: The High Principles Expressed Herein Are Purely Propaganda, to Be Taken Seriously Only at Your Own Risk.

WILLIAM KREHM, 1944 (20)

In early 1944, radio listeners in El Salvador were assured several times a day that "[Y]ou don't ask for liberty, you conquer it. United, the United Nations will triumph." Somewhat anticlimactically, the radio announcer continued with the advice to "take Mejoral" for "your headaches" (Krehm 21). Sterling Products, the U.S. manufacturer of Mejoral aspirins, had its slogan from the Office of the Coordinator of Inter-American Affairs (OCIAA), the U.s. government's agency for the coordination of wartime relations with the Latin American republics, which blanketed the continent with pro-Allies propaganda during World War II. William Krehm, a U.s. journalist critical of his country's policies in Latin America, claimed at the time that the ociAA was "blissfully unaware of the dynamite it was sending into Latin America's tyrant-ridden lands." El Salvador was indeed "tyrant-ridden:" the dictatorial regime of Maximiliano Hernández Martínez had been in power for thirteen years by the end of the war. Things were about to change, however. During the spring of 1944 a failed military uprising followed by a successful civilian strike toppled Martínez and inaugurated an all-too brief experiment with civilian, democratic government in El Salvador. Appropriately, the same radio announcer who told Salvadorans to take liberty (and aspirins) also announced the fall of the dictator (Krehm 21).

This brief anecdote raises a number of important questions about U.S. wartime diplomacy in El Salvador. Firstly, what role did authoritarian regimes

\footnotetext{
* This article references to a large degree hitherto unpublished sources from the National Archive of the United States. In order to facilitate the reading experience, the references to archival material have been relegated to the footnotes.

(C) JORRIT VAN DEN BERK, 2018 | DOI 10.1163/9789004292017_013
}

This is an open access chapter distributed under the terms of the prevailing CC-BY-NC License at the time of publication. 
such as that of Martínez play in the U.s.-led wartime alliance against European dictatorship and Japanese militarism? Secondly, how did the U.s. government, through the activities of the OCIAA, frame its informational programs for El Salvador? Following up on that question, how were these programs received by various audiences in the country? Did they lead to the anti-dictatorial revolution against Martínez, as William Krehm seems to imply? Lastly, how did U.s. diplomats respond to that revolutionary activity? In answering these questions, this contribution seeks to explain what meaning U.S. public diplomacy programs acquired in the context of Salvadoran politics during World War II. ${ }^{\dagger}$

Considering the extent of wartime propaganda activities in Latin America, several scholars suggest that a connection must exist between U.s. public diplomacy and the (temporary) demise of dictatorship throughout the Western Hemisphere. Exactly how such propaganda was received by local audiences remains unclear, however. It is unlikely, as Krehm believed, that U.s. propaganda caused resistance to local dictatorships, especially since such opposition predates the foundation of the OCIAA. A key assumption behind the argument set forth in this text is that the anti-authoritarian movement that surfaced in El Salvador by the end of the war was largely indigenous in its origins and ideologies. ${ }^{1}$ As this paper will show, however, Salvadorans regularly adopted the language of the war and referred to wartime programs when they confronted U.s. diplomats with the contradictions in their nation's foreign policy. The latter were slow to recognize that the ideology of World War II could have any

$\dagger$ A note on terminology: throughout this text I will use terms such as "public diplomacy," "informational programs" or "propaganda" interchangeably to refer to u.s. efforts to influence audiences in El Salvador. My use of these terms is not intended to convey my judgment on the activities of the OCIAA, nor does it reflect adherence to any particular theoretical framework. Following conventions in the field of Latin American studies, I will use the term "America" to refer to nations of the Western Hemisphere and "U.s." to refer to the United States of America.

1 Victor Bulmer-Thomas, The Political Economy of Central America since 1920 (Cambridge University Press: New York, 1987), 101; Patricia Parkman, Nonviolent Insurrection in El Salvador. The Fall of Maximiliano Hernández Martínez (University of Arizona Press: Tucson, 1988), 32-33; Leslie Bethell and Ian Roxborough, "Introduction: The Postwar Conjuncture in Latin America: Democracy, Labor, and the Left," in idem eds., Latin America between the Second World War and the Cold War, 1944-1948 (Cambridge University Press: New York, 1992), 1-32, there 6-7; David Rock, "War and Postwar Intersections: Latin America and the United States," in idem ed., Latin America in the 1940s: War and Postwar Transitions (University of California Press: Berkeley, 1994), 15-40, there 19-21; Thomas M. Leonard, "The OIAA in Central America: The Coordinating Committees at Work," in Gisela Cramer and Ursula Prutsch eds., ;Américas Unidas! Nelson A. Rockefeller's Office of Inter-American Affairs (1940-1946) (Vervuert: Frankfurt, 2012), 283-312, there 288. 
meaning in El Salvador and, in the end, U.s. diplomacy proved too inflexible to adapt to the new directions that Salvadorans set out for themselves. In that sense, the current text adds a critical note to this volume by tracing the potential and ultimate insignificance of "liberation" in a region that the United States had long considered its own "backyard."

Both U.s. public diplomacy and its relation with Latin American dictators during World War II should be understood against the background of the rise and decline of the Good Neighbor policy during the 1930s and 1940s. Observing Latin American hostility toward U.s. military, diplomatic, and economic intervention throughout the 1920s, the Franklin Roosevelt administration had adopted the so-called Good Neighbor policy toward the nations of the Western Hemisphere when it came into office in 1933. The backbone of that policy was U.S. recognition of the sovereignty and equality of all the nations of the Americas and, by extension, the adoption by the United States of the nonintervention principle. The Roosevelt administration withdrew U.s. troops from Haiti and Nicaragua; negotiated an end to the Platt Amendment to the Cuban constitution, which gave the U.s. the right to intervene in the island's politics; and ended the non-recognition policy by which Washington had tried to push Salvadoran President Martínez out of office.

Historical assessments of the Good Neighbor policy and especially the practice of nonintervention have developed over time. According to Bryce Wood, it was because of the Good Neighbor that, by 1939, "the United States had established, with the assistance of certain Latin American states, an unprecedented set of relationships productive of a nearly solidary American attitude toward threats from without." Especially when compared to the lack of Latin American enthusiasm for cooperation during World War I and the later Korean War, the support that the United States received from its Latin American allies during World War II was, according to Wood, the greatest triumph for the Good Neighbor. Only toward the end of the war did U.s. interventionism reemerge when Ambassador Spruille Braden attempted to preempt the election of Juan Perón in Argentina. From that time onward, the Good Neighbor was steadily "dismantled" (Wood 1961 and 1985).

Wood's argument represents a generation of historians who regard U.S.Latin American cooperation during World War II as a high point for the Good Neighbor policy, before the relationship soured again during the Cold War. More critical voices emphasize the continuity between the early zoth century and the Cold War (see Gilderhus 91-96). According to Lars Schoultz, for example, the Good Neighbor represents only a tactical break with the interventionist past. While military incursions ended, Washington started to rely on local dictators to protect its interests during the 1930s. The war only strengthened these ties. 
The U.s. supported the dictators in the interest of local stability and the dictators supported the U.s. in order to be eligible for lend-lease aid, flexible trade and financial agreements, and prestigious United Nations status. After the war, the strong bonds with local military regimes "would facilitate the transmission of anticommunist values to Latin America" (Schoultz 310).

The wartime alliance of American republics, which eventually included every nation but Argentina, was undoubtedly a great diplomatic victory for the Roosevelt administration. However, Schoultz raises an important issue by drawing our attention to the fact that before, during, and after the war, the United States worked closely with authoritarian regimes, especially in Central America and the Caribbean. Yet, wartime diplomacy was not only an extension of earlier policies. It was mainly during the war itself that the celebrated nonintervention principle was silently abandoned. Washington introduced new treaties for the use of Central American airfields and harbors; arrangements to share intelligence; assistance in the blacklisting of German economic interests; collaboration with local security forces, including the supply of lend-lease equipment; extensive propaganda campaigns to sell the purpose of the war to American allies; programs for the deportation of Axis nationals; and many more initiatives. During the war years, U.s. legations (embassies from 1943 onward) in Central America were expanded to be able to deal with the vast amounts of work relating to the war. Cultural attachés and FBI agents ("legal attachés") were sent to all American republics to conduct propaganda programs and to gather intelligence on "non-American" activities. These men were joined by military instructors who were to ease the introduction of U.S. armaments to the sister republics and economic advisors to wage economic war on Axis nationals. These new activities were also accompanied by more benign programs for the improvement of roads, hospitals, sewers, agricultural techniques, and educational programs. ${ }^{2}$

Recent historical interpretations acknowledge that Washington abided by the nonintervention principle more or less faithfully through the 193os, but

2 An overview of State Department wartime programs can be found in: John E. Findling, Close Neighbors, Distant Friends: United States-Central American Relations (Greenwood Press: New York, 1987), chapter 5. For military programs, see:John Child, Unequal Alliance: The inter-American Military System, 1938-1978 (Westview Press: Boulder, 1980), 27-62. For an overview of cultural programs, see: Frank A. Ninkovich, The Diplomacy of Ideas: U.s. Foreign Policy and Cultural Relations, 1938-1950 (Cambridge University Press: New York, 1981), 35-61. For local economic developments and the role of U.s. economic warfare, see: BulmerThomas, Political Economy, 87-100. Also consult references below for information on specific programs and activities. 
abandoned it during, rather than after the war. Max Paul Friedman argues that "overblown fears of an external threat to the hemisphere brought about the end of the Good Neighbor policy during the Second World War, not the Cold War." As Friedman demonstrates, U.s.-German economic rivalry and exaggerated concerns for the existence of a Nazi "fifth column" in Latin America escalated into a U.s.-led deportation program during the war. Part of a broader program of economic warfare against German interests in the Western Hemisphere, thousands of Germans and Japanese and hundreds of Italians were deported from Latin American nations and interned in the United States on the mere assumption that they posed a threat to U.s. security. Much like Schoultz, Friedman observes that it was the dictatorships of Latin America who were especially keen to cooperate with the United States. Many local strongmen used the program to their advantage as the properties of German deportees were expropriated, offering new opportunities for enrichment and graft. The democratic nations more carefully guarded their sovereignty against U.s. interference and tried to protect the interests of deportees who were often long-time residents or citizens of the nations in question (Friedman 230).

U.s. public diplomacy in Latin America should be understood within this context of wartime interventionism. In order to strengthen "economic and cultural ties with Latin America and ensure hemispheric solidarity in the face of a growing Axis presence," the Roosevelt administration founded the Office for the Coordination of Commercial and Cultural Relations between the American Republics (later Office of the Coordinator of Inter-American Affairs, or OCIAA). Headed by Nelson Rockefeller, the OcIAA initiated a range of projects, but it is best known for its cultural activities. Combining private initiative with government coordination, the OCIAA promoted the dissemination of Hollywood movies, radio shows, news items, and printed materials throughout the continent. According to Uwe Lübken, policymakers regarded the cultural programs as a benign alternative to forceful intervention, which was still taboo under the Good Neighbor. ${ }^{3}$ When viewed in the context of other wartime programs, however, it is clear that OcIAA propaganda represents one side to a more interventionist policy.

3 Uwe Lübken, "Playing the Cultural Game: The United States and Nazi Threat to Latin America," in Cramer and Prutsch, jAméricas Unidas!, 53-76. For more information on the OCIAA, consult other articles in the aforementioned volume as well as: Darlene J. Sadlier, Americans All. Good Neighbor Cultural Diplomacy during World War II (University of Texas Press: Austin, 2012). 
The OcIAA headquarters in Washington relied on coordinating committees in each Latin American nation to adapt its programs to local contexts and to disseminate information through such sources as were available. Coordinating committees were established in Central America in 1942 and their staffs of volunteers were recruited from U.s. businessmen with connections in local communities. Each committee worked with certain constraints, the most important of which were the interests that their voluntary staffs took in their task; the attitudes of the local government and the local U.s. embassy; and the communications infrastructure of the host nation. In El Salvador, the most important obstacle to the committee's effectiveness turned out to be the limited infrastructure of the country, especially outside of the capital city of San Salvador. The committee distributed news materials to newspaper, spread posters and pamphlets, offered scripts for radio programs, and showed movies, among a variety of smaller activities. However, due to poor transportation facilities and restricted radio ownership, the committee's main audiences were the upper and middle classes of the capital.

According to Thomas Leonard, the OCIAA informational programs for Central America concentrated on "the military strength of the United States, its wealth, resources, and productive capacity; its traditional concept of freedom and tolerance, and its lack of imperialistic motives; its sincere effort toward improved social conditions for all; and the importance of culture in American life." By mid-1943, the coordinating committee in El Salvador had come to focus on the themes of inter-American solidarity and postwar economic and social ties. The U.s. ambassador in El Salvador also noted widespread attention for the Four Freedoms and Atlantic Charter, which were, "blazoned by us throughout El Salvador in the form of posters." As the coordinating committees kept careful track of their audience's main interests, we know that the middle and upper classes in Central America expected a postwar world with strong ties to the United States and the possibility of greater participation in more democratic governments. Whether those expectations were directly linked to U.s. programs, is, in the words of Leonard, one of "the most perplexing aspects" of the coordinating committees' work. ${ }^{4}$

4 The discussion of the OcIAA in El Salvador is based on: Thomas M. Leonard, "The OIAA in Central America," in Cramer and Prutsch, iAméricas Unidas!, 283-312. The quotation of the U.s. ambassador is from: Ambassador Walter Thurston to the Secretary of State, despatch 1123, December 30, 1943, National Archives of the United States at College Park, MD, Record Group 84: Records of the Foreign Service Posts of the Department of State, Legation in San Salvador [henceforth: PRES], box 82, class 80o: Salvador. 
As the OcIAA set up its activities, Central America's small middle sector was expanding and asserting itself. Through natural increase and rural-urban migration, the middle sector had become an identifiable element in the populations of Central American capitals by the 1940s. However, this growing class was not represented in the political system. In El Salvador, upwardly mobile groups such as university students and junior military officers saw their social advancement cut short by the Martínez regime, which was dominated by a stagnant and aging group of senior officers and government officials. During the war, moreover, economic growth in Central America's urban centers fell behind due to the decline in commerce, causing further frustration for middle sector groups. These social and economic factors combined with the "espousal of the Atlantic Charter and Roosevelt's Four Freedom" would add up to "a powerful case for political change," according to Victor Bulmer-Thomas. The developing middle class opposition movement was "heartened" by the idealism of the war, Patricia Parkman finds, because it conferred respectability and legitimacy to its ambitions. ${ }^{5}$

As the United States fought the dictators of Europe and the ocIAA spread its propaganda about political freedoms and socio-economic improvements, Washington worked closely with several dictators in Latin America. U.s. policymakers did not perceive this paradox until it was pointed out to them by local oppositionists (on which more below). Through the early years of the war the cooperative attitude of Central American dictators was actually instrumental in allowing U.S. diplomats to uphold the fiction that the nonintervention policy was still valid. Authoritarian regimes had been established throughout the hemisphere following the economic and social turmoil of the Great Depression. In Central America, Jorge Ubico (1931-1944) came to power in Guatemala, Maximiliano Hernández Martínez (1931-1944) in El Salvador, Tiburcio Carías Andino (1932-1948) in Honduras, and Anastasio Somoza García (1936-1956) in Nicaragua. The strongmen of the Caribbean were Rafael Trujillo (19301961) of the Dominican Republic and Fulgencio Batista of Cuba (1933-1959). Having adopted the nonintervention policy, Washington did not contest the rise of dictatorship in its sphere of influence, although Friedman argues that

5 Bulmer-Thomas, PoliticalEconomy, 100-104, quote on 101; Parkman, Nonviolent Insurrection, $30-45$, quote on $32-33$. Victor Hugo Acuña Ortega adds an important caveat to these findings, showing that some middle class groups had a vested interest in the continuation of the authoritarian state: Victor Hugo Acuña Ortega, "The Formation of the Urban Middle Sectors in El Salvador, 1910-1944," in Aldo Lauria-Santiago and Leigh Binford, Landscapes of Struggle: Politics, Society, and Community in El Salvador (University of Pittsburgh Press, 2004), 39-49. 
the dictators' pro-American attitude and status-quo policies made it easier for the United States to assume the role of a good neighbor (Frieman 230). In any event, all were staunch allies of the U.s. during World War II.

Many programs that were deemed essential to the war effort in the Americas could only be accomplished with the consent or active collaboration of local governments, whether they were democratic or authoritarian. Economic warfare against German companies, for example, could only be executed through cooperation with the local governments - to the point where the U.s. legation in Guatemala prepared the laws that the local government needed to implement to make economic warfare possible. ${ }^{6}$ While the rhetorical commitment to the Good Neighbor remained, new definitions and justifications were necessary to harmonize wartime activities with a supposed attitude of nonintervention. In 1941, for example, U.s. Minister to El Salvador Robert Frazer argued that encouraging Salvadoran newspapers to print "solidarity-of-the-Americans propaganda" did not constitute intervention: "[T] regard the exercise of such an influence [over the Salvadoran press] as circumscribing their independence is, we think, perhaps an extreme view. As a matter of fact, the entire press of Salvador is pro-Pan-American anyhow, so that no paper would be violating its principles or sacrificing its ideals by printing [U.s. propaganda]. ${ }^{77}$ Frazer's argument is ingenious, since the Salvadoran press was strictly censored by the Martínez regime.

Interestingly, the Department of State became concerned about the "impression" prevalent in some Latin American countries that the United States had "abandoned its popular nonintervention policy during the War." The Axis nations were using this sentiment to their advantage, the Department believed, with propaganda about "Yankee Imperialism": "The pretext for this propaganda is the increasing activity of this government in various enterprises on the soil of the other American republics: the construction and operation of military and naval bases, the Proclaimed List, deportations, a wide variety of economic operations (ranging from the war-connected rubber programs to projects with a pronounced 'welfare' aspect, such as the health and sanitation program)."

6 John Moors Cabot, memorandum, October 17, 1941, National Archives of the United States, College Park, MD, Record Group 59: Department of State Lot Files [henceforth: Lot Files], entry 211: Individual Countries [henceforth: entry 211], box 46, folder marked Guatemala, 1936-1942.

7 Minister Robert Frazer to the Secretary of State, despatch 1437, July 2, 1941, PRES, Strictly Confidential Files [henceforth: SCF], box 5, class 891: Public Press. 
The Department patently rejected the notion that such activities were acts of intervention: "After all, intervention on behalf of special groups in the United States [a reference to business interests] has not been revived." Furthermore, all U.S. activities were executed on the basis of "collaboration" and "what can honestly be described as [the] interests of the whole hemisphere." This turned out to be the magic formula. As long as local collaborators could be found and as long as the objectives of the United States could be described as serving a common cause, the Department was not, in fact, intervening: "We must get off the defensive. The expression 'nonintervention' should give way to 'collaboration', as a sign of changed conditions." Although it was not acknowledged at the time, the problem remained that local collaborators might use their connections to U.S. programs to increase their own power and prestige. Also, there was no democratic method by which the definition of the "common good" could be established - the State Department would take it upon itself to determine that.

In their search for local "collaborators," U.s. legations in Central America relied more and more on their association with the local dictatorships. In the wartime context, the military dictators of Central America turned out to be peculiarly useful allies. Not only were they particularly keen to follow U.s. policies, they also had standing armies, intelligence networks, permissive laws against subversion, and propaganda machines that could — with a little help and direction from the United States - be employed to fight the perceived fifth column threat. The only liberal country in Central America, Costa Rica, was at a disadvantage in this regard: "German and Italian activities in Costa Rica date from the very beginning of the Nazi and fascist regimes in Germany and Italy. This is accounted for by the fact that [...] the Government of Costa Rica is democratic in every sense of the word and activities could therefore be carried on without any hindrance." ${ }^{9}$ Ironically then, the most democratic republic of the isthmus was most vulnerable to totalitarian subversion.

The argument that the United States supports right-wing dictatorships to maintain stability and security in its sphere of influence is well-known (see Schmitz 1999). The experience of the war strengthened that tendency in specific ways. U.s. diplomats developed new justifications for collaborating with

8 "Propaganda about Relations between this Government and the other American Republics," September 17, 1942, Lot Files, American Republic Affairs, entry 214: Miscellaneous Memorandums, January 4, 1938 to September 12, 1947 [henceforth: entry 214], box 66, folder marked Chapin and Toop, 1941 to December 1942.

9 Cabot, Strictly Confidential Memorandum for Mr. Overton G. Ellis, n.d. (September, 1941), PRES, SCF, box 42, volume vi, class 500: Congresses and Conferences. 
dictatorships in the context of a global crisis and a local fifth column threat. Such justifications would reemerge during the Cold War. The authoritarian regimes in Central America benefitted from military missions and FBI instructors who were sent to Central America to train the local security forces in the use of modern weapons, intelligence gathering, and surveillance-increasing the regimes' capability to control their own populations. ${ }^{10}$ The ociAA financed the dictators' official press and supplied upbeat "information" about the war and the United Nations - thus strengthening the impression that the dictators were important allies of the United States. Economic advisors helped the local authorities to nationalize German interest-giving the regimes new sources for graft and illegal enrichment. U.s. engineers built roads, sewers, hospitals, and schools with U.s. funds-but the local leaders claimed that the new services were the result of their modernizing policies.

This complex interplay of developments on international and national levels - U.S. wartime interventionism, including the propaganda activities of the OCIAA, and the existence of a friendly dictatorship, together with an expanding, restless middle class - would shape the meaning of World War II in El Salvador. Throughout the war years, the Martínez regime and local oppositionists competed with each other to lay claim to the war on fascism in order to translate their goals to U.s. diplomats. That process began even before the United States entered the war. In September, 1941, a group of former government employees, urban professionals, and young intellectuals formed two new organizations: The Acción Democrática Salvadoreña (Salvadoran Democratic Action, ADs) and the Juventud Democrática Salvadoreña (Democratic Salvadoran Youth, JDS). Formally, these were not political parties, but civic organizations that wished to support the Allied cause by promoting democratic ideals and counteracting the spread of totalitarianism. The regime was not duped, however. Shortly after the founding of said organizations, the Salvadoran minister of foreign affairs visited U.s. Minister Frazer to warn him that ADS and JDS were in fact anti-government parties and therefore, naturally, communistic and pro-Nazi. The Martínez government was somewhat embarrassed by the situation because it was on record as promoting democracy and opposing totalitarianism itself, but, argued the president and the foreign minister,

10 John H. Coatsworth, Central America and the United States: The Clients and the Colossus (Maxwell Macmillian: New York, 1994), 45-48 argues that U.s. military aid significantly increased the power and the prestige of local military establishments. Leonard argues that the influence of U.S. military aid was slight: Thomas M. Leonard, "Central America: On the Periphery," in Leonard and John F. Bratzel eds., Latin America during World War II (Rowman \& Littlefield: Lanham, 2007), 50-53. 
the present world crisis required unity and patriotism in the face of threats. If the members of ADS and JDS were genuinely interested in the defense of democracy, they could join El Salvador's sole legal party: the Partido Nacional Pro-Patria. The fact that they did not proved that they were only interested in creating division. Some weeks later, ADS and JDS were outlawed. ${ }^{11}$

The U.s. legation had witnessed opposition to the Martínez regime before, most notably in $193^{2}$ when indigenous communities in western El Salvador rebelled, subsequently to be massacred by government troops (see Anderson 2001). These episodes had generally been disregarded by U.S. diplomats as being purely local affairs. This time it was different, because the members of ADS and JDS were not peasants, professional politicians, or disgruntled army officers, but former government officials, physicians, lawyers, and professorsin a word, close friends and acquaintances of the legation. ${ }^{12}$ Moreover, in the parlance of democracy, the new organizations found a theme that related to traditional Salvadoran civic culture, the interests of its middle class supporters, and the war against fascism. Frazer reported to the Department that it was ridiculous to characterize ADS as communist or pro-Nazi, as the local government did, because its members were "all prominent, conservative and patriotic. Most of them are known to have resigned office because, although formerly in full accord with the President [Martínez], they disagree with the extension of his presidential term and his continuation of a de facto dictatorship." When, in October, the government formally restricted the right of assembly and presented this as a measure to deal with enemy activities, Frazer reported that the

11 Francisci Lime to Frazer, September 19, 1941, PRES, SCF, box 4, class 8oo: Accion Democratica; Frazer to the Secretary of State, despatch 1715, September 22, 1941, PRES, SCF, box 4, class 8oo: Accion Democratica; Frazer, Memorandum on Visits by Drs Araujo and Avila re New Democratic Parties, September 23, 1941, PRES, SCF, box 4, class 8oo: Accion Democratica; Frazer to the Secretary of State, despatch 1720, September 24, 1941, PRES, SCF, box 4, class 800: Accion Democratica; Frazer to the Secretary of State, despatch 1727, September 24, 1941, PRES, SCF, box 4, class 8oo: Accion Democratica.

Later in the war, Ambassador Walter Thurston and members of his embassy would describe known members of the opposition as "competent," "outstanding," and "highly reputed" attorneys, journalists, and engineers. They were also described as "proAmerican" and "friends of the embassy," several of whom had visited the United States on official exchanges or had studied there. Thurston to the Secretary of State, despatch 1156, January 8, 1944, PRES, box 98, volume XIII, class 80o: Salvador. General; Thurston to the Secretary of State, despatch 1351, March 2, 1944, PRES, box 98, volume XIII, class 8oo: Salvador. General; Ellis, Confidential Memorandum for the Ambassador, March 14, 1944, PRES, box 98, volume XIII, class 80o: Salvador. General. 
decree was obviously directed at "legitimate" opposition such as that of ADS and that it was enacted 'in spite of President Martínez' reiterated statements of his belief in and support for democracy."13

Notwithstanding Frazer's reports, only the middle level of the Department demonstrated a passing interest in the matter. The suppression of ADS and JDS almost coincided with the United States' formal entry into the war. When former members of the, now illegal, ADs visited Frazer at the legation on December 18, only 11 days after Pearl Harbor, the minister could not help but sympathize with those "sincere men of high ideals, actuated by unselfish, patriotic motives." They left a manifesto with the minister that expounded their ideals, perhaps in a last effort to involve U.s. diplomats in their conflict with the regime. Writing his report on the meeting that evening, Frazer regretfully noted that there was nothing more he could do to help, since the Department had already been notified about the situation but, under the circumstances, could not act "without indulging in improper criticism of President Martínez' administration." "This memorandum, therefore, is being filed merely to complete the records." ${ }^{m 4}$

Minister Frazer's experience with ADS and JDS is indicative of attempts by Central American actors, both representatives of the regime and its opposition, to appropriate the language of the World War and to use it, successfully at times, to translate their own politics to U.s. diplomats in a way that would elicit attention and sympathy. It was already noted how the experience of war led U.s. diplomats to construct new justifications for their cooperation with Latin American dictators in their fight against European dictators. It should be stressed, however, that local leaders like Martínez actively contributed to the construction of that perception.

In early 1943, for example, Martínez told the newly arrived U.s. ambassador, Walter Thurston, that "liberty" in El Salvador was not the kind of liberty that a North American might be used to-playing up to U.s. prejudices regarding Latin Americans' "political maturity" and implicitly rejecting the applicability

13 Frazer to the Secretary of State, despatch 1720, September 24, 1941, PRES, SCF, box 4, class 8oo: Accion Democratica; Frazer to the Secretary of State, despatch 1740, October 3, 1941, PRES, SCF, box 4, class 80o: Accion Democratica.

14 Secretary of State to Frazer, instruction 464, October 8, 1941, PREs, box 4, class 8oo: Government; Frazer to the Secretary of State, despatch 1777, October 16, 1941, PRES, box 4, class 801: Government; Frazer, Memorandum on Call at Legation of Dr. Francisco A. Lima and Six Other Members of the Central American Committee of the Acción Democrática Salvadoreña, December 18, 1941, PRES, SCF, box 4, class 800: Accion Democratica. 
of the Four Freedoms to El Salvador. At the same time, the regime tried to convince the population that the United States supported it. In his weekly speeches, which were themselves modelled on Roosevelt's fireside chats, Martínez regularly referred to wartime cooperation and the many u.s. projects to improve roads, sanitation, and agriculture in El Salvador-suggesting that his regime provided an irreplaceable link between Salvadorans and Washington's largesse. Complementing the government's public propaganda was a "whispering campaign": planted rumors that suggested that the United States would never accept a change of regime during the war. Naturally, Martínez needed some more substantial signs of U.S. support to back up his claims. So, on July 7 , Thurston was officially invited to attend a banquet in Santa Anna in honor of Martínez, which turned out to be the official kick-off of Martínez' latest reelection campaign. The embassy found out about the real purpose of the banquet when it was too late to decline the formal invitation outright without causing something of a diplomatic scandal. Even more deviously, the Salvadoran regime attempted to get a U.s. fiat for constitutional changes that were necessary to keep Martínez in power beyond 1944 by claiming that a review of the country's first law was necessary to allow for the expropriation and sale of "Axis" possessions in El Salvador. ${ }^{15}$

15 Thurston to the Secretary of State, despatch 1, January 14, 1943, PRES, box 76, class 123: Thurston; Thurston to the Secretary of State, despatch 214, March 23, 1943, PRES, box 82, class 802.1: Executive Departments; Thurston to the Secretary of State, despatch 259, April 6, 1943, PrEs, box 82, class 802.1: Executive Departments; Thurston to the Secretary of State, despatch 269, April 8, 1943, Pres, box 82, class 802.1: Executive Departments; Thurston to the Secretary of State, despatch 115, February 19, 1943, PRES, box 82, class 803: Legislative Branch; Ellis to Thurston, September 9, 1943, PRES, SCF, box 8, volume I, class 8oo: El Salvador; Gerhard Gade, untitled memorandum, July 19, 1943, PRES, box 82, class 80o: El Salvador; Thurston to the Secretary of State, despatch 624, July 19, 1943, PrEs, box 82, class 80o: El Salvador; Thurston to Mauricio Callardo, July 24, 1943, PRES, SCF, box 8, volume I, class 8oo: El Salvador; Thurston to the Secretary of State, despatch 618, July 28, 1943, PRES, SCF, box 8, volume I, class 8oo: El Salvador; Thurston to the Secretary of State, despatch 498, June 26, 1943, PRES, SCF, box 8, volume I, class 711.3: Proclaimed List; Acting Secretary of State to Thurston, instruction 259, July 27, 1943, PRES, SCF, box 8, volume I, class 711.3: Proclaimed List; Thurston to the Secretary of State, despatch 966, November 16, 1943, PRES, SCF, box 8, volume I, class 711.3: Proclaimed List; Thurston to the Secretary of State, despatch 1080, December 16, 1943, PRES, SCF, box 8, volume I, class 711.3: Proclaimed List; Thurston to the Secretary of State, despatch 1119, December 29, 1943, PRES, SCF, box 8, volume I, class 711.3: Proclaimed List. 
The underground, middle class opposition movement also aligned its goals with those of the war and also sought the support of the U.s. embassy. Trying to avoid censorship, the opposition press published editorials and open letters to President Roosevelt on the ideals of the United Nations while, in the opinion of Ambassador Thurston, "transparently alluding to local conditions." Oppositionists visited the ambassador and sent him letters and memoranda on the establishment of civic societies in support of the fight against fascism. While many of those communications were careful to avoid direct criticism of the regime, others were more explicit in their assertion that the Martínez government was a despotism "equal in pride and vanity to those we fight abroad."16

Toward the end of 1943, a local student organization, the Frente Democrático Universitario (University Democratic Front, FDU), attempted to involve the embassy more directly in its protests against the regime. On December 4, the students presented a plan to Thurston to hold a parade on the anniversary of Pearl Harbor, supposedly to demonstrate their support for the Four Freedoms and Atlantic Charter and their solidarity with the people of the United States. The students asked the embassy for U.s. flags, pictures of President Roosevelt, and posters about the Four Freedoms to brighten their parade. The march would end at the embassy and its climax would be a speech in support of the United States, which (in its eventual form) called on "Latin American citizens" to "vigorously fight" the transplantation of fascism "on our continent."17

Thurston's natural inclination as an experienced "Good Neighbor" was to avert all attempts to draw him into local politics - which he did with considerable skill. On the one hand, the ambassador discouraged the "scoundrels" of the regime to seek his help. Being unable to ignore the invitation to the government's banquet in Santa Anna outright, Thurston convinced the organizers that pressing matters prevented his attendance and sent two lower ranking officers in his place. Seeing through the regime's ploy to involve the embassy in a reform

16 J. Cipriano Castro to Thurston, June 20, 1943, PREs, box 82, class 80o: Political Affairs, Salvador (translation from Spanish by the author). The 1943 files contain many opposition letters and embassy reports on opposition activity. For a non-exhaustive sample covering the month of September, see: "El Pueblo Salvadoreño" to Thurston, September 4, 1943, PRES, box 82, class 8oo: Salvador; Asociacion Nacional Democrática to Thurston, September 21, 1943, PRES, box 82, class 80o: Salvador; Frente Magisterial Democrático to Thurston, September 28, 1943, PRES, box 82, class 800: Salvador.

17 Rafael Eguizábal h. et al. to Thurston, December 4, 1943, PREs, box 82, class 80o: Salvador; "Discurso pronunciado ante la estatua de la Libertad por el Sr. Rafael Eguizábal h., a nombre del Frente Democrático Universitario, con occasion del homenaje a los Estados Unidos de América, el 11 de diciembre de 1943," PREs, box 82, class 800: Salvador (translations from Spanish by the author). 
of the constitution, the embassy informed authorities that the United States had requested no changes to the constitution; that Salvadoran laws enabling the prosecution of the war were deemed adequate; and that the government should make no attempt to convey the impression that the United States was in any way involved with the contemplated revisions. Perhaps Thurston's most significant action was to cancel the shipment of 1,000 U.s. sub-machineguns to the Salvadoran government. Navy intelligence had informed the legation that these weapons would probably be distributed to members of Pro Patria, to be used against the opposition in imitation of the 1932 massacre. $^{18}$

Having deflected the regime's attempts to draw his embassy into local politics, Thurston felt that he had to take the same position in his dealings with the opposition. Thus, the ambassador often received oppositionists personally and politely listened to their criticism of the government, only to inform them that he was completely neutral in the matter. The case of the student demonstration offered something of a challenge since its purported intention was to support the allied cause. Initially, the ambassador informed the students that he appreciated their initiative, but that he could not support their parade of December 8, as President Roosevelt had recently vetoed a bill proposing to commemorate the yearly anniversary of Pearl Harbor. Having no intention to give up that easily, the students informed Thurston that they would happily postpone their parade to December 11, the day that war was declared on fascism. This time, Thurston could only offer the rather thin excuse that he wished all manner of celebration to be called off until final victory in the war was secure. Without the embassy's patronage, the student parade, intended to be a grand affair with much waving of the Salvadoran and U.s. flags, turned out to be a modest gathering of some 400 nervous students (one sixth of whom, in the estimate of the U.S. military attaché, were actually undercover policemen). While the government did not break up the supposedly pro-allied demonstration, some of the student

18 Thurston to the Secretary of State, despatch 430, June 4, 1943, PREs, box 82, class 8oo: Salvador; Thurston to Callardo, July 24, 1943, PRES, SCF, box 8, volume I, class 80o: El Salvador; Thurston to the Secretary of State, despatch 618, July 28, 1943, PRES, SCF, box 8, volume I, class 8oo: El Salvador; Thurston, untitled memorandum, June 21, 1943, PRES, SCF, box 8, volume I, class 8oo: El Salvador; D.V.R., Memorandum on Projected Reform of the Salvadoran Constitution, June 29, 1943, PRES, SCF, box 8, volume I, class 80o: El Salvador; Maleady to the Secretary of State, telegram 150, July 20, 1943, PRES, SCF, box 8, volume II, class 824: Equipment and Supplies; Major C.P. Baldwin to Thurston, July 23, 1943, PRES, SCF, box 8, volume II, class 824: Equipment and Supplies; Lieutenant R.W. Rastetter to Thurston, August 26, 1943, PRES, SCF, box 8, volume II, class 824: Equipment and Supplies. 
leaders were spirited away by what oppositionists had come to describe, tellingly, as the Gestapo Martínista. The disappointed students would later impress upon Thurston the analogies between Martínez' action and those of the European dictators and asked the ambassador's help to firmly implant the Four Freedoms and the Atlantic Charter ("los Cuatro Libertades del Atlántico") in El Salvador. ${ }^{19}$

The failure of Salvadoran students to obtain the embassy's patronage did not mark the end of oppositionists' attempts to draw the United States into their local war with dictatorship. However, the tone of their communications became increasingly bitter. Through a local u.s. businessman named Winall Dalton, Thurston was in touch with several Salvadoran oppositionists who observed that while the State Department would not intervene against the dictators, it had in fact intervened on many occasions during the war and therefore had a "moral responsibility" toward the Salvadoran opposition. The United States, Dalton's friends said, had intervened to keep Nazi-sympathizers from being appointed to government offices; to deport Axis nationals and liquidate their property; to protect U.s. economic interests; to plant pro-Allied information in the papers and to supply lend-lease weapons to the regime. Furthermore, Minister Frazer had publically defended the Martínez regime and its cooperative stance during the war and had allowed the dictator to adopt the pro-democratic language of the war while he was in effect a "nazifascist." Aside from the political and economic angle:

You intervened, with sincere sentiments we desire to believe, to give us sewers and modern slaughterhouses, swimming pools and bridges, highways and schoolchildren feeding-programs. WHY? [...] We have had no voice in accepting these gifts you have brought. You have dealt with the illegal government your legation helped to perpetuate and your country

19 Thurston to the Secretary of State, despatch 1070, December 13, 1943, PRES, box 82, class 8oo: Salvador; Thurston, untitled memorandum, September 8, 1943, PRES, box 82, class 8oo: Salvador; Thurston to the Secretary of State, despatch 955, November 12, 1943, PRES, box 82, class 8oo: Salvador; Thurston to Eguizábal h., December 4, 1943, PRES, box 82, class 800: Salvador; Eguizábal h. to Thurston, December 6, 1943, PREs, box 82, class 8oo: Salvador; Thurston, untitled memorandum, December 11, 1943, PRES, box 82, class 8oo: Salvador; Eguizábal h. to Thurston, December 13, 1943, PRES, box 82, class 8oo: Salvador; Thurston to the Secretary of State, despatch 1070, December 13, 1943, PREs, box 82, class 80o: Salvador; G.B. Massey to Thurston, December 14, 1943, PRES, box 82, class 8oo: Salvador; Oswaldo Escobar Velado and Eguizábal h. to Thurston, December 13, 1943, PRES, box 82, class 800: Salvador. 
has sustained by recognition. We resent this Good Neighbor program of yours - we do not want charity and you offend us by extending it. You are a great and powerful people - why do you give us sewers but aid in the denial of Human Rights?

Dalton's letters on behalf of the opposition represent the gap that had come to exist between the United States' experience of fighting a war for democracy and the Central American experience of living under a U.s. supported dictatorship. "Will it not be shameful for you Americans to see our people mowed down by your General Grant tanks? Could you not find a better and honorable use for them-or scrap them if you have too many?", this letter pleaded, "To whom do you pretend to be a Good Neighbor? To the dictator or to the people of El Salvador?"20

Salvadoran oppositionists did not ask the ambassador to put a halt to U.s. intervention. Rather, they pointed out that the United States should take responsibility for the ways in which it was influencing Salvadoran politics and acknowledge the promises it had made in the Atlantic Charter and the Four Freedoms. For example, an unnamed Salvadoran attorney, "whose friendship for the United States is not open to doubt," told a member of the embassy in a private conversation that "he considered the avowed policy of the United States not to interfere in the internal policies of the Latin American countries as prejudicial to the cause of democracy and liberty [...] asserting that thereby, the United States encouraged dictatorships in power." Rather, this Salvadoran believed that Washington should institute a policy of non-recognition of dictators. A manager of an independent (though censored) newspaper volunteered to a member of the embassy the "feelings of resentment and frustration" that his colleagues felt about the way in which U.s. activities in El Salvador were "allowed to be converted to the prestige of the Martínez administration." According to this newspaperman, the publishers of the independent newspapers had considered a "declaration of war" on the U.s. by refusing to publish the materials of the OcIAA. On another occasion however, the pressmen had considered to remind Nelson Rockefeller of the cooperation that they had furnished to him and to insist that he help them in return by getting Washington to withdraw its diplomatic recognition of the regime. ${ }^{21}$

20 Winnall A. Dalton to Thurston, December 28, 1943, PREs, box 82, class 80o: Salvador.

21 Thurston to the Secretary of State, despatch 1123, December 30, 1943, PRES, box 82, class 8oo: Salvador; Thurston to the Secretary of State, despatch 1156, January 8, 1944, PRES, box 98, volume XIII, class 80o: Salvador. General; R.T.S., confidential memorandum, March 10, 1944, PREs, box 98, volume XIII, class 8oo: Salvador. General. 
In January 1944, the coordinating committee in El Salvador also concluded that Washington's collaboration with Martínez impaired U.s. prestige, though it is not clear whether the activities of local oppositionists had any role to play in the formation of that view. At any rate, Ambassador Thurston could no longer ignore the issue. In a report to the Department, Thurston wrote with apparent surprise that "[o]ur pronouncements such as the Atlantic Charter and the Declaration of the Four Freedoms (the latter blazoned by us throughout El Salvador in the form of posters) are accepted literally by the Salvadorans as official endorsement of basic democratic principles which we desire to have prevail currently and universally." Salvadorans could not reconcile these pronouncements, the ambassador continued, with U.s. collaboration with the dictators of the American continent. As Thurston now understood the problem, "[t]he principle defect of a policy of non-intervention accompanied by propaganda on behalf of democratic doctrines simultaneously stimulates dictatorships and popular opposition to them." He counseled the Department to consider this dilemma, cautioning that "a problem of this complex nature is not susceptible of ready solution and the most that should be attempted at this time is an empirical search for improvements and careful study of plans for a revision of policy after the war."22

Unfortunately for Thurston, Salvadorans would not await the outcomes of careful study. In May 1944, following a failed military uprising, a revolution started with a student strike that spread throughout the capital, gradually paralyzing the city. Remembered as the huelga de los caídos brazos (sit-down strike) the protests were a successfully executed campaign of non-violent resistance against state terror (see Parkman 1988). Initially, Martínez belittled the significance of the insurrection and blamed it on "agitators employing well-known Nazi war-of-nerves tactics." Ultimately, he tried to strike back by bringing armed peasants to the city. Martínez' cabinet ministers and advisors managed to convince the president not to let the situation escalate, however, and the latter decided to step down. The president's retirement was announced over the national radio on May 9, and power was transferred to a provisional government under the leadership of Minister of Defense Andrés Ignacio Menéndez. The opposition, which was not entirely satisfied by Menéndez' appointment, kept up the pressure for some days, until Martínez fled to Guatemala and the interim government announced its intention, in the language of the war, to govern "according to the norms of the most ample democracy, guaranteeing

22 Thurston to the Secretary of State, despatch 1154, January 8, 1944, PRES, box 98, volume XIII, class 80o: El Salvador. 
the Four Freedoms proclaimed by Mr. Roosevelt." While the U.s. had taken no active part in the change of government, Salvadorans closely identified Martínez' resignation with the war effort: "Four Freedoms posters and improvised variations thereon were carried throughout the city by the multitude celebrating the occasion. Several demonstrations-some small and some numbering several thousand-paraded to [the U.s.] Embassy cheering the United States."23

The Salvadoran experiment with democracy lasted for only four months, but was characterized by feverish activity. Some ten political parties were formed-or came out into the open-in the two months after Martínez' downfall. Some were radical, some reactionary, but all referred in some way or another to the democratic ideology of the war. ${ }^{24}$ New newspapers were

23 Thurston to the Secretary of State, telegram 136, May 5, 1944, PRES, box 99, volume XIV, class 8oo: El Salvador; Thurston to the Secretary of State, telegram 141, May 7, 1944, PRES, box 99, volume XIV, class 8oo: El Salvador; Thurston to the Secretary of State, telegram 152, May 9, 1944, PREs, box 99, volume XIV, class 8oo: El Salvador; A.F.M., memorandum on political situation, May 10, 1944, PRES, box 99, volume XIV, class 80o: El Salvador; Thurston to Boaz Long, May 11, 1944, PREs, box 99, volume XIV, class 8oo: El Salvador; Thurston to the Secretary of State, telegram 159, May 11, 1944, PRES, box 99, volume XIV, class 8oo: El Salvador; Thurston to the Secretary of State, despatch 1555, May 12, 1944, PRES, box 99, volume XIV, class 80o: El Salvador; Thurston to the Secretary of State, despatch 1557, May 12, 1944, PREs, box 99, volume XIV, class 80o: Salvador. General; Parkman, Nonviolent Insurrection, especially 62

24 This trend is noticable in the names of the new parties: Unión Democrática Nacional, Partido Emancipación Nacional, Frente Popular Salvadoreño, Partido Unión Demócrata, Partido del Pueblo Salvadoreño, Frente Social Republicano, Partido Fraternal Progresista, and Partido Unificación Social Democrática. Not all parties were as progressive as their names suggested: Partido Fraternal Progresista, for example, was led by an old caudillo while Partido Unificación Social Democrática represented conservative coffee interests. It is indicative of the prestige of democratic principles that even the old coffee barons felt obliged to acknowledge it in the name of their party. Thurston to the Secretary of State, despatch 1628, May 26, 1944, PRES, box 99, volume XIV, class 80o: Salvador. General; Thurston to the Secretary of State, despatch 1644, May 29, 1944, PRES, box 99, volume XIV, class 80o: Salvador. General; Thurston to the Secretary of State, despatch 1648, May 29, 1944, PREs, box 99, volume XIV, class 80o: Salvador. General; Thurston to the Secretary of State, despatch 1658, May 31, 1944, PRES, box 99, volume XIV, class 8oo: Salvador. General; Thurston to the Secretary of State, despatch 1662, June 2, 1944, PRES, box 99, volume XIV, class 80o: Salvador. General; Thurston to the Secretary of State, despatch 1687, June 5, 1944, PRES, box 99, volume XIV, class 80o: Salvador. General; Gerhard Gade to the Secretary of State, despatch 1753, June 22, 1944, PRES, box 99, volume XIV, class 8oo: Salvador. General; Gade to the Secretary of State, despatch 1756, June 24, 1944, PRES, box 99, volume XIV, class 80o: Salvador. General. 
published while existing newspapers began to express editorial comments freely, one such paper announcing that "The triumph of the United States of North America is our triumph. It signifies our independence. ${ }^{m 5}$ The revolution in El Salvador was part of a broader development throughout Latin America. Several long-lived dictatorships were toppled by opposition movements that were at least partly inspired by U.s. wartime propaganda. Jumping on the bandwagon, the Department of State initially expressed careful satisfaction with the trend and, in 1945, it instituted its own policy of denouncing "dictatorships and disreputable governments" in Latin America. Unfortunately, right-wing forces would reassert their power quickly, so that, by the beginning of the Cold War, many Latin American countries were under the sway of conservative and military governments. ${ }^{26}$

The democratic revolution in El Salvador was ended in October 1944, by an army coup led by Colonel Osmín Aguirre y Salinas, a veteran of the 1932 slaughter and, in the view of the U.s. embassy, a fascist-sympathizer. Under pressure from local opponents and the United States, which initially refused to extend recognition to the new regime, Aguirre stepped aside for another president, but the liberal factions of El Salvador would not regain their strength after the October coup. Aguirre's brief sway did lead to an important and perhaps definite break between the U.s. embassy and the democratic opposition. In March 1945, just days before Aguirre would step down, the Department of State decided to recognize the regime in order to be able to invite the Salvadoran government for a meeting of the American ministers of Foreign Affairs in Mexico. ${ }^{27}$ From Washington's perspective, the conference in Mexico was an important step in its evolving postwar policy toward Latin America, but many Salvadorans were shocked that the United States chose to work with a man of Aguirre's background. In the days and weeks after recognition, the embassy in San Salvador received hate mail in such quantities that a separate file marked "protests against recognition" was created in its archives. Many letters accused the United States of fascist policies; some contained more traditional denunciations

25 Thurston to the Secretary of State, despatch 1557, May 12, 1944, PRES, box 99, volume XIV, class 8oo: Salvador. General; Thurston to the Secretary of State, despatch 1576, May 17, 1944, PRES, box 99, volume XIV, class 80o: Salvador. General.

26 Bethell and Roxborough, "The Postwar Conjuncture," 2, 5, and 18-19.

27 Cabot to Messersmith, December 21, 1944, Lot Files, entry 211, box 46, folder marked El Salvador, 1940-1947; Messersmith, Memorandum on Telephone Conversation with Toriello, February 14, 1945, Lot Files, entry 211, box 46, folder marked El Salvador, 1940-1947. 
of "Yankee imperialism"; at least one letter was accompanied by a picture of Franklin Roosevelt adorned with swastikas. ${ }^{28}$ While the fact that the Salvadoran opposition, as an organized body, never regained its old strength must have played a role in the development, it is noteworthy to observe that throughout the following years there was very little contact between the U.s. embassy and oppositionists.

At that time, the new U.s. ambassador to El Salvador, John Farr Simmons, still considered the group of "forward-looking liberals, small in number but strongly influenced by Jeffersonian concepts of democracy," to be the best hope for El Salvador's future. It was fortunate that these "liberals" were "more articulate" than in any other Central American countries and that they patterned their "ideals upon the democratic processes of our country." However, their "liking and respect for the United States [suffered] a severe setback at the time of our recognition of the Aguirre regime." If the United States was serious about its policy against "disreputable governments," Simmons argued, the liberal element in El Salvador "should be given every encouragement [because] in the long run, [it] is our greatest hope for the future in the gradual establishment in this country of what we understand as the democratic process." This advice came too late. Over the course of the next years, the Salvadoran military strengthened its grip on the country while Washington's tolerance for political experimentation in Latin America declined as the Cold War set in.

U.s. diplomats never fully grasped what meaning the ideals of World War II, sold locally by the OCIAA, had for Salvadorans. Ambassador Walter Thurston understood how both the Martínez regime and local oppositionists claimed the war. The former stressed the need for solidarity and stability and used the expropriation of "Axis" properties as an excuse to tamper with the constitution. The latter pushed the analogy between the fight against European dictatorship and its own fight against dictatorship. Thurston believed that by adhering to the traditional nonintervention policy, he could avoid being entangled in local politics. However, the nonintervention policy was, to all intents and purposes, a fiction by 1943. The State Department itself emphasized "collaboration" for the "common good," fully aware of the fact that this would mean cooperation with dictatorship in many Latin American countries. Liberally-minded Salvadorans came to resent U.s. wartime programs, including the democratically flavored propaganda of the OCIAA, because they could not harmonize what was to them obviously an 
interventionist policy with the ambassador's refusal, based on the nonintervention principle, to distance his country from the Martínez regime.

By 1944, Thurston came to believe that a nonintervention policy combined with propaganda in favor of democracy stimulated both dictatorship and opposition against it. By framing the issue in these terms, however, Thurston revealed how far apart he and Salvadoran oppositionists really were. Firstly, the many letters that the embassy received from local oppositionists reveal that they did not regard nonintervention, by itself, as the central problem. The real problem was that U.s. wartime programs benefited the dictatorship of Martínez. Secondly, it is unlikely, as Thurston believed, that pro-democratic propaganda caused opposition to Martínez. Neither did Salvadoran oppositionists ever recognize the United States as the source of their ideals. Rather, they adopted the language of the war in their communications with u.s. diplomats in order to extend a moral claim on U.S. support in favor of the ideals that it was spreading through the work of the OcIAA. Lastly, by counseling the Department to subject the problem of dictatorship and democracy to careful empirical study after the end of the war, Thurston demonstrated a complete lack of understanding for the urgency of Salvadorans' desire for democracy. A little over four months after Thurston wrote his report, Martínez had been toppled.

Regarding the question of the meaning of U.s. wartime propaganda in El Salvador, this text has provided a partial answer. While scholars tend to portray the OCIAA's public diplomacy as comparatively benign cultural program, Salvadorans came to interpret it in the context of U.s. intervention and collaboration with a dictatorship that was quickly loosing support. While the war and U.s. wartime informational programs undoubtedly contributed to the opposition against dictatorship in Central America, as several historians have already suggested, it is important to note that Salvadorans were not passive recipients of such propaganda. Whether Salvadoran oppositionists actively subscribed to the message of the OCIAA or believed that it reflected a serious commitment of the United States to the spread of democracy is a question that requires further research. What is clear from the many opposition letters and the placards and flags that Salvadorans carried in their marches on the embassy, is that they adopted the language of public diplomacy to recruit the United States in their local struggle for their liberation. If U.s. diplomats had been able to imagine a democratic future for Central America, it might well have offered Washington an opportunity to play a more positive role in the region than it did once the Cold War had begun. 


\section{Bibliography}

Acuña Ortega, Victor Hugo. 2004. The Formation of the Urban Middle Sectors in El Salvador, 1910-1944. In Landscapes of Struggle: Politics, Society, and Community in El Salvador, ed. Aldo Lauria-Santiago and Leigh Binford, 39-49. Pittsburgh: University of Pittsburgh Press.

Anderson, Thomas P. 2001. Matanza: The 1932 "Slaughter" that traumatized a Nation, shaping U.s.-Salvadoran Policy to this Day. Willimantic: Curbstone Press.

Bethell, Leslie and Ian Roxborough. 1992. Introduction: The Postwar Conjuncture in Latin America: Democracy, Labor, and the Left. In Latin America between the Second World War and the Cold War, 1944-1948, ed. Leslie Bethell and Ian Roxborough, 1-32. New York: Cambridge University Press.

Bulmer-Thomas, Victor. 1987. The Political Economy of Central America since 1920. New York: Cambridge University Press.

Child, John. 1980. Unequal Alliance: The inter-American Military System, 1938-1978. Boulder: Westview Press.

Coatsworth, John H. 1994. Central America and the United States: The Clients and the Colossus. New York: Maxwell Macmillian.

Findling, John E. 1987. Close Neighbors, Distant Friends: United States-Central American Relations. New York: Greenwood Press.

Friedman, Max Paul. 2003. Nazis and Good Neighbors: The United States Campaign against the Germans of Latin America in World War II. New York: Cambridge University Press.

Gilderhus, Mark T. 200o. The Second Century: U.S.-Latin American Relations since 1889. Wilmington: Scholarly Resources.

Krehm, William. 1984. Democracies and Tyrannies of the Caribbean. Westport: Lawrence Hill and Company.

Leonard, Thomas M. 2007. Central America: On the Periphery. In Latin America during World War II, ed. Leonard and John F. Bratzel, 50-53. Lanham: Rowman \& Littlefield.

Leonard, Thomas M. 2012. The OIAA in Central America: The Coordinating Committees at Work. In jAméricas Unidas! Nelson A. Rockefeller's Office of InterAmerican Affairs (1940-1946), ed. Gisela Cramer and Ursula Prutsch, 283-312. Frankfurt: Vervuert.

Lübken, Uwe. 2012. Playing the Cultural Game: The United States and Nazi Threat to Latin America. In ¡Américas Unidas! Nelson A. Rockefeller's Office of Inter-American Affairs (1940-1946), ed. Gisela Cramer and Ursula Prutsch, 53-76. Frankfurt: Vervuert.

Ninkovich, Frank A. 1981. The Diplomacy of Ideas: U.S. Foreign Policy and Cultural Relations, 1938-1950. New York: Cambridge University Press. 
Parkman, Patricia. 1988. Nonviolent Insurrection in El Salvador. The Fall of Maximiliano Hernández Martínez. Tucson: University of Arizona Press.

Rock, David. 1994. War and Postwar Intersections: Latin America and the United States. In Latin America in the 1940s: War and Postwar Transitions, ed. David Rock, 15-40. Berkeley: University of California Press.

Sadlier, Darlene J. 2012. Americans All. Good Neighbor Cultural Diplomacy during World War II. Austin: University of Texas Press.

Schmitz, David F. 1999. "Thank God They're on our Side": The United States and RightWing Dictatorships, 1921-1965. Chapel Hill: University of North Carolina Press.

Schoultz, Lars. 1998. Beneath the United States: A History of U.S. Policy toward Latin America. Cambridge: Harvard University Press.

Wood, Bryce. 1961. The Making of the Good Neighbor Policy. New York: Columbia University Press.

Wood, Bryce. 1985. The Dismantling of the Good Neighbor Policy. Austin: University of Texas Press. 